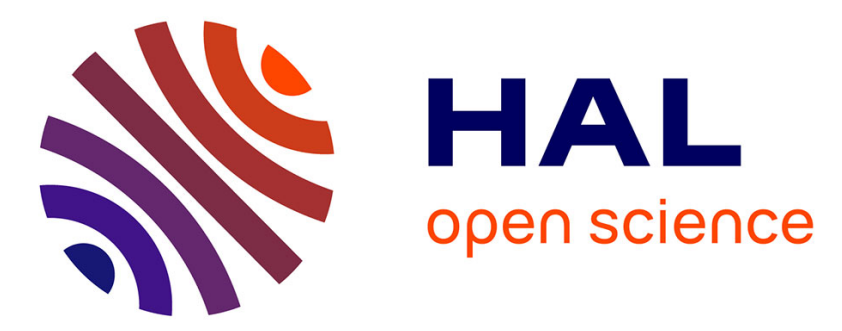

\title{
Molecular Biological Characterization of Avian Poxvirus Strains Isolated from Different Avian Species
}

\author{
Giovanni Manarolla, Giuliano Pisoni, Giuseppe Sironi, Tiziana Rampin
}

\section{To cite this version:}

Giovanni Manarolla, Giuliano Pisoni, Giuseppe Sironi, Tiziana Rampin. Molecular Biological Characterization of Avian Poxvirus Strains Isolated from Different Avian Species. Veterinary Microbiology, 2009, 140 (1-2), pp.1. 10.1016/j.vetmic.2009.07.004 . hal-00535913

\section{HAL Id: hal-00535913 https://hal.science/hal-00535913}

Submitted on 14 Nov 2010

HAL is a multi-disciplinary open access archive for the deposit and dissemination of scientific research documents, whether they are published or not. The documents may come from teaching and research institutions in France or abroad, or from public or private research centers.
L'archive ouverte pluridisciplinaire $\mathbf{H A L}$, est destinée au dépôt et à la diffusion de documents scientifiques de niveau recherche, publiés ou non, émanant des établissements d'enseignement et de recherche français ou étrangers, des laboratoires publics ou privés. 


\section{Accepted Manuscript}

Title: Molecular Biological Characterization of Avian Poxvirus Strains Isolated from Different Avian Species

Authors: Giovanni Manarolla, Giuliano Pisoni, Giuseppe Sironi, Tiziana Rampin

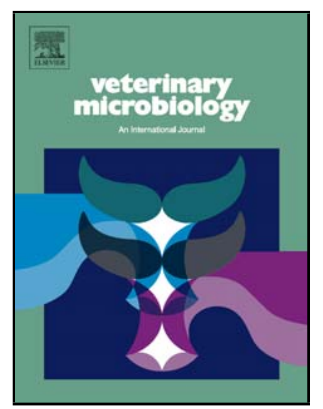

PII: $\quad$ S0378-1135(09)00323-X

DOI: $\quad$ doi:10.1016/j.vetmic.2009.07.004

Reference: $\quad$ VETMIC 4493

To appear in: $\quad$ VETMIC

Received date: $\quad 14-1-2009$

Revised date: $\quad 19-6-2009$

Accepted date: $\quad$ 1-7-2009

Please cite this article as: Manarolla, G., Pisoni, G., Sironi, G., Rampin, T., Molecular Biological Characterization of Avian Poxvirus Strains Isolated from Different Avian Species, Veterinary Microbiology (2008), doi:10.1016/j.vetmic.2009.07.004

This is a PDF file of an unedited manuscript that has been accepted for publication. As a service to our customers we are providing this early version of the manuscript. The manuscript will undergo copyediting, typesetting, and review of the resulting proof before it is published in its final form. Please note that during the production process errors may be discovered which could affect the content, and all legal disclaimers that apply to the journal pertain. 
1 MOLECULAR BIOLOGICAL CHARACTERIZATION OF AVIAN

2 POXVIRUS STRAINS ISOLATED FROM DIFFERENT AVIAN SPECIES

3

4 Giovanni Manarolla, Giuliano Pisoni, Giuseppe Sironi, Tiziana Rampin

5

6 Università degli Studi di Milano, Dipartimento di Patologia Animale, Igiene

7 e Sanità Pubblica Veterinaria, via Celoria 10, 20133 Milano, Italy

8

9

10 corresponding author: Phone number 00390250318104 Fax number 0039

110250318106 email address: giovanni.manarolla@unimi.it

12

13 


\section{ABSTRACT}

15 Fifteen strains of Avipoxvirus from different avian species were isolated

16 and molecular-biologically characterized. Most strains did not produce

17 evident pocks on the chorioallantoic membranes of commercial and

18 specific-pathogen free embryonated chicken eggs where, on the contrary,

19 microscopic signs of viral growth were always detected. Polymerase chain

20 reaction of highly conserved $\mathrm{P} 4 \mathrm{~b}$ gene was positive for all cases confirming

21 to be a reliable diagnostic method for Avipoxvirus. Sequencing of these

22 amplicons confirmed most strains clustered either with Fowlpox virus or

23 with Canarypox virus whereas a possible new clade could be hypothesized

24 for one strain from Japanese quail. Classification of Avipoxvirus strains by

25 amplification of the newly identified locus fpv140 revealed major

26 limitations as only five samples were positive. These results underline the

27 importance to undertake similar studies on higher numbers of Avipoxvirus

28 isolates and on wider genomic regions of this large viral group.

29

30 Keywords: Avipoxvirus, virus isolation, PCR, sequencing 


\section{INTRODUCTION}

34 The poxviruses belong to the Poxviridae family, whose members are large,

35 oval to brick-shaped enveloped DNA viruses. Their genome consists of 36 double-stranded DNA ranging from 130000-375000 nucleotides in linear 37 configuration. They replicate within the cytoplasm of the cells they infect 38 (Gubser et al., 2004; Jarmin et al., 2006). The poxvirus family is subdivided 39 into the Entomopoxvirinae and Chordopoxvirinae subfamilies, which infect 40 insects and chordates, respectively (Moss, 2001 cited by Gusber et al., 2004). 41 Within the Chordopoxvirinae subfamily, Avipoxvirus (APV) is the only 42 characterized genus that can infect non-mammalian hosts (Moss, 2001 cited 43 by Gusber et al., 2004), including more than 230 of the known 9000 avian 44 species with a worldwide distribution (Bolte et al., 1999, Tulman et al., 2004).

45 Nevertheless, APV includes only the following species: Canarypox virus, 46 Fowlpox virus, Juncopox virus, Mynahpox virus, Pigeonpox virus, 47 Psittacinepox virus, Quailpox virus, Sparrowpox virus, Starlingpox virus and 48 Turkeypox virus. Three more species - Peacockpox virus, Penguinpox virus, 49 Crowpox virus - are still referred to as tentative by the International Commitee 50 on Taxonomy of Viruses (www.ncbi.nlm.nih.gov/ICTVdb/Ictv/index.htm).

51 APVs cause diseases in avian species that are usually referred to as pox and 52 are characterized by two main forms: the cutaneous form and the diphtheritic 53 form. In poultry, this disease can cause significant economic losses associated 54 with decreased egg production, reduced growth, and increased mortality 55 (Tripathy and Reed, 2003). Pox in canary is usually associated with extremely 56 high mortality rates due to severe pulmonary damage. The possibility for 
57 APVs to threaten the sustainability of populations of endangered birds has

58 been also described (Tripathy et al., 2000).

59 The conventional laboratory diagnosis of APVs is carried out by

60 histopathologic examination, electron microscopy, virus isolation on

61 Chorioallantoic Membrane (CAM) of embryonated chicken eggs or cell

62 cultures, and serologic methods (Tripathy and Reed, 1998). Recently,

63 molecular biological methods have proven to be the most sensitive techniques

64 for the routine diagnosis. In particular, Polymerase Chain Reaction (PCR)

65 based on the amplification of a 578-base pair (bp) region of the highly

66 conserved P4b gene of APVs had been increasingly used for diagnosis in the

67 last few years (Lüschow et al., 2004). Live vaccines against fowlpox made

68 with chicken strains are commercially available to protect chickens and

69 turkeys as well. Additionally, vaccines against canarypox, pigeon pox and

70 quail pox exist, each made with virus strains originating from the specific

71 avian species. In the last few years, the request for new vaccines against APV

72 infections have been increasing to protect a wider range of avian species,

73 particularly endangered species such as some birds of prey. Little is known

74 about the host range of APVs, although it is generally assumed to be limited

75 (Bolte et al., 1999; Jarmin et al., 2006). Moreover, the number of the species

76 and tentative species listed in the genus Avipoxvirus

77 (www.virustaxonomyonline.com) is much smaller than the number of bird

78 species naturally infected by pox and, consequently, the attribution of an APV

79 strain to a novel species within the genus APVs requires biologic, antigenic

80 and genetic characterization (Kim et al., 2003). Although poxvirus genome

81 organization, replication, host range and pathogenesis have been studied 
extensively (Moss, 2001 cited by Gusber et al., 2004), less is known about the evolutionary relationships of these viruses. Recently, the number of poxvirus genome sequences submitted to the databases has increased considerably. Much recent interest in the poxviruses has centred on their use as virus vectors (Gusberg et al., 2004). Moreover, the increasing interest for APV is partially due to the possible threat such pathogens may play in limiting the population of endangered birds as recently described by Tripathy et al. (2000).

Still little information exists about the phylogenetic relationships among APVs. More details about their evolution could be valuable to better understand their host spectrum, epidemiology and pathogenesis. Recently, phylogenetic studies, focused on the sequencing of $\mathrm{P} 4 \mathrm{~b}$ gene, have pointed out that the vast majority of APV isolates clustered into the two major Clades of the phylogenetic trees, i.e. Fowlpox virus (Clade A) and Canarypox virus (Clade B) (Lüschow et al., 2004; Weli et al., 2004; Jarmin et al., 2006). Attempts to identify new loci would permit a more robust classification of APVs. Recently, Jarmin et al. (2006), sequenced locus fpv140 of some strains of APVs. Their results suggest that the size of the primary product of the fpv140 locus PCR allows easy distinction between Clades A and B, being 1800 bp and 2400 bp, respectively.

This study is aimed at obtaining a more comprehensive phylogenetic framework for the APVs by analysing P4b and fpv140 loci of APV strains isolated from naturally occurring cases of pox infections in different avian species. 
MATERIALS AND METHODS

108 Viruses:

109 The study was based on $\underline{15}$ strains collected as fragments of cutaneous or

110 pulmonary pox lesions during routine diagnostic activity. Two

111 commercially available vaccine strains against fowlpox and canarypox were

112 also included. The avian species of origin, month and year of collection are

113 listed in Table 1.

114

115 Virus isolation: Tissue samples were stored at $-20^{\circ} \mathrm{C}$ until use. Samples

116 from each clinical case were minced and ground with sterile quartz sand

117 using a mortar and pestle, suspended in a balanced salt solution containing

$11850 \mathrm{IU} / \mathrm{ml}$ penicillin and $50 \mu \mathrm{g} / \mathrm{ml}$ streptomycin. Following low-speed

119 centrifugation at $100 \times \mathrm{g}$ for $10 \mathrm{~min}, 0.1 \mathrm{ml}$ of the supernatant of the $1 \underline{5}$

120 suspensions was inoculated on the CAMs of 11-day-old chicken embryos

121 from commercial and Specific-Pathogen Free (SPF) (SPAFAS ${ }^{2}$ ) line as

122 well. The inoculated eggs were incubated at $37.5^{\circ} \mathrm{C}$ for 7 days and then

123 examined for pocks on the CAM. No further passages were carried out.

124 Samples of each CAM were collected for histopathology.

126 Histopathology

127 Tissue samples collected from each clinical case and from each CAM were

128 fixed in $10 \%$ buffered formalin embedded in paraffin, sectioned at $4 \mu \mathrm{m}$ and

129 stained with haematoxylin and eosin.

130

131 DNA extraction and PCR amplification 
132 DNA was extracted from $25 \mathrm{mg}$ of the skin or pulmonary lesions of all the

133 clinical cases and from $25 \mathrm{mg}$ of the two lyophilized vaccines by QIAamp

134 DNA Mini Kit (Qiagen, Italy, Milan) following the manufacturer's

135 guidelines. Tissue digestion with proteinase $\mathrm{K}$ was performed at

$13656^{\circ} \mathrm{C} /$ overnight. The DNA concentration was measured fluorometrically and

137 DNA samples were stored at $-80^{\circ} \mathrm{C}$ until analysis.

138 PCR reactions for APV-specific PCR and for fpv140 as well consisted of 25

$139 \mu \mathrm{l}$ PCR buffer containing $1.5 \mathrm{mM}$ of $\mathrm{MgCl}_{2}, 6$ pmol of each primer, $200 \mu \mathrm{M}$

140 of each dNTP and 1.25 U Taq polymerase (Invitrogen, Milan, Italy).The

141 APV-specific PCR was performed using a primer pair described by Huw

142 Lee \& Hwa Lee (1997) based on P4b sequence of Fowlpox virus strain

143 HP444 (forward primer: 5'-CAGCAGGTGCTAAACAACAA-3': reverse

144 primer: 5'-CGGTAGCTTAACGCCGAATA-3'). Identical protocol as

145 described by Lüschow et al. (2004) was used with the exception of clinical

146 isolate QP-241, whose optimal annealing temperature $\left(50^{\circ} \mathrm{C}\right)$ was

147 established by gradient PCR. Amplification was performed after initial

148 denaturation for $2 \mathrm{~min}$ at $94^{\circ} \mathrm{C}$ for 35 cycles and consisted of $1 \mathrm{~min}$

149 denaturation at $94^{\circ} \mathrm{C}, 1 \mathrm{~min}$ annealing at $60^{\circ} \mathrm{C}$, and $1 \mathrm{~min}$ extension at $72^{\circ} \mathrm{C}$.

150 A final extension step was performed for 2 min at $72^{\circ} \mathrm{C}$. Fpv140 was

151 amplified by PCR as described by Jarmin et al., (2006) using a forward

152 primer with slight modification, 5'-GAAGTAGAGTTATCGGTTC-3', and

153 the same reverse primer M2912, 5'-GGTGATCCATTTCCATTTC-3'.

154 Amplification was performed after initial denaturation for $5 \mathrm{~min}$ at $94^{\circ} \mathrm{C}$ for

15535 cycles, and consisted of 1 min denaturation at $94^{\circ} \mathrm{C}, 1$ min annealing at

$15655^{\circ} \mathrm{C}$, and 2 min extension at $72^{\circ} \mathrm{C}$. A final extension step was performed 
157 for $15 \mathrm{~min}$ at $72^{\circ} \mathrm{C}$. Then, five microlitres of the amplified PCR products

158 were separated by $2 \%$ (for $\mathrm{P} 4 \mathrm{~b}$ ) and $1.2 \%$ (for fpv140) agarose gel

159 electrophoresis and stained with ethidium bromide. PCR products of $\mathrm{P} 4 \mathrm{~b}$

160 gene with the specific size were purified by QIAquick PCR purification kit

161 (Qiagen, Milan, Italy), and both strands sequenced by BMR Genomics

162 (Padova, Italy). The sequences were submitted to the GenBank database

163 under accession numbers listed in Table 1.

164 After manual editing and excluding primer regions the P4b sequences ( $\underline{504}$

$165 \mathrm{bp}$ ) were aligned (clustalW; Thompson et al., 1994) with APV sequences

166 available from GenBank (Table 2) and possible genetic relationships and

167 phylogenetic grouping of the different APVs were investigated using the

168 neighbour-joining method according to the Jukes and Cantor model.

169 Molluscum contagiosum virus (MOCV) was used as an outgroup for P4b.

170 The reliability of the tree topologies was tested by bootstrap analysis $(1,000$

171 resampling). Pairwise genetic and amino acid distances of those strains

172 displaying greater variability in the phylogenetic tree were calculated by

173 MEGA version 3.1 (Kumar et al., 2001), applying the default setting, with

174 the exception that all sites with ambiguous codes and gaps were ignored.

176 RESULTS

177

178 Virus isolation

179 No appreciable differences between commercial and SPF eggs were

180 observed out. Macroscopically, pocks were evident for samples PA9554,

181 PA9678, PA295-93, PA262-06 and PA213-07 respectively from song 
182 thrush (the first two), canary, gyrfalcon and turkey. Small and single lesions

183 were detected for samples QP-241 (Japanese quail) and PA153-05 (common

184 buzzard). The CAMs inoculated with the other samples appeared

185 moderately thickened and oedematous or quite normal (Table 3).

186

187 Histopathology

188 The histological evaluation of the cutaneous lesions revealed marked

189 hyperkeratosis and achantosis associated with multifocal ulcers, cellular

190 debris and large aggregates of cocci. Most keratinocytes were characterized

191 by ballooning degeneration with large intracytoplasmic, 15 to $20 \mathrm{~mm}$, pale

192 eosinophilic inclusions surrounded by a clear halo (Bollinger bodies).

193 Proliferative bronchitis associated with numerous characteristic poxviral

194 inclusions were observed in the pulmonary lesions. Evidence of viral

195 replication varying in severity was observed in the CAMs collected from all

196 the inocula and consisted of focal hypertrophy and hyperplasia of the CAM

197 epithelium associated with ballooning degeneration and Bollinger bodies.

198 Oedema and fibroplasia of varying severity and heterophilic infiltration

199 were also detectable in all samples.

200

$201 \quad$ PCR and sequencing

202 APV-specific DNA was detected in the vaccine samples and in the lesion

203 samples from all the clinical cases. The size of all the amplified products of

204 the P4b gene (about $580 \mathrm{bp}$ including primers) was in agreement with the

205 size of the published nucleotide sequences (Figure 1). The derived

206 phylogenetic trees are shown in Figure 2. All the strains of this study except 
207 that from quail (QP-241) can be included into Clade A (Fowlpox virus) or

208 Clade B (Canarypox virus) according to the phylogenetic classification by

209 Jarmin et al. (2006). One strain from grey partridge (PA4078), one from

210 canary (PA1-09-92), one of the two strains from pheasant (PA9922), and the

211 isolate from turkeys (PA213-07) clustered in subclade A1, whereas the

212 second strain from grey partridge (PA7761), strain PA295-93 from canary,

213 strains PA153-05 from common buzzard, and strain PA262-06 from

214 gyrfalcon belonged to subclade A2. The isolates from pigeon (PA303-94),

215 dunnock (PA248-07), hooded crow (PA147-07), song thrush (PA9554 and

216 PA9678), and one strain from canary (PA7746) belonged to subclade B1.

217 Mean distance percentage of $27.4 \%$ and $28.7 \%$ was evaluated between

218 nucleotide sequences of QP-241 and Clade A and B respectively, of 23.7\%

219 between PA1-09-92 and subclade B1, 8.3\% between PA4078 and PA7761,

$2203.4 \%$ between PA147-07 and subclade B1 and 2.7\% between PA9678 and

221 subclade B1. Mean distance percentage of $18 \%$ and $23.8 \%$ was evaluated

222 between derived amino acid sequences of QP-241 and Clade A and B

223 respectively. Amplification of the gene fpv140 gave PCR positive results for

2247 strains including the two vaccines (Figure 3). Amplicons from canarypox

225 vaccine, and from the canary samples 7746 and PA1-09-92 were $2400 \mathrm{bp}$

226 whereas amplicons from fowlpox vaccine and from PA9922, PA295-93, and

227 PA 153-05 (pheasant, canary and common buzzard respectively) were 1800

228 bp. The other isolates were all negative. 


\section{DISCUSSION}

232 Fifteen strains of APVs from clinical cases affecting different avian species

233 were isolated and characterized by molecular biological methods to increase

234 the knowledge about the complex relationships between these viruses and

235 their hosts. All cases occurred in Northern Italy and were diagnosed during 236 routine diagnostic activity. Some of the APV strains infected avian species

237 where APVs are not or rarely reported (song thrush, grey partridge,

238 dunnock, hooded crow) (Bolte et al., 1999). Interestingly, the onset of some

239 episodes was registered in wintertime (Table 1) when APV infections are

240 considered to be uncommon. Although only one passage was carried out,

241 virus isolation gave some interesting results. Commercial eggs were used

242 first. Seven strains produced evident pocks on the CAMs whereas such

243 gross lesions were not observed with the other strains (Table 3). Whether

244 pocks were visible or not, evidence of viral growth was detected

245 microscopically in all the CAMs (Table 3). The multifocal distribution of

246 such findings excluded the site of injection as the limited area of viral

247 replication. It is well known that some APV strains, especially from wild

248 avian species, have no or poor growth in embryonated eggs or cell cultures

249 (Tripathy \& Reed, 1998; Krone et al., 2004). Our histopathological results

250 pointed out all the 15 strains did grow in embryonated eggs after just one

251 passage thus suggesting their possible ability to adapt to the embryos. This

252 will be investigated in future studies. The possible role of maternal

253 antibodies against fowlpox in the unapparent and limited growth of most

254 strains on eggs from commercial breeders (Rampin et al., 2007) was ruled 
out, inasmuch as the same inocula were subsequently injected into SPF eggs

256 with strictly comparable results.

257 As for the molecular biological analysis, gene $\mathrm{P} 4 \mathrm{~b}$ amplification products of 258 the expected size were obtained for all the strains of this study, thus 259 confirming that PCR is an extremely valuable diagnostic method for APV 260 infections. Sample QP-241 required gradient PCR to assess optimal 261 annealing temperature, as the protocol published by Lüschow et al. (2004) 262 gave no result. Sequencing of these amplicons revealed that all of our 263 isolates but QP-241 cluster in the two major Clades of APVs: A (Fowlpox 264 virus) and B (Canarypox virus) (according to Jarmin et al., 2006) (Figure 2). 265 Strain QP-241 from Japanese quail was known to have peculiar 266 characteristics among APVs (Rinaldi et al., 1972). Sequencing of its P4b 267 gene revealed mean distance percentages of $27.4 \%$ and $28.7 \%$ with Clade A 268 and $\mathrm{B}$, respectively, corresponding to $18 \%$ and $23.8 \%$ mean amino acid 269 distance. As the mean distance percentage between nucleic acid sequences 270 of Clade A and B is $25 \%$, a possible new Clade of belonging for strain QP271241 could be proposed. This is supported by previous reports which showed 272 DNA trees with a third major clade consisting of APVs from psittacines 273 (Lüschow et al., 2004; Jarmin et al., 2006). Psittacines viruses display 274 peculiar nucleic acids changes and this is in accord with in vivo cross275 protection studies (Jarmin et al., 2006). Similarly, QP-241 from Japanese 276 quail was proven to have unique biological characteristics. Nevertheless, its 277 genetic divergence needs to be ascertained through study of larger genomic 278 regions. Interestingly, only another sequence of $\mathrm{P} 4 \mathrm{~b}$ gene from Japanese 279 quail (Table 1-DQ873809) was found in the GenBank database, but it 
280 phylogenetically belongs to Clade A2. As for the other strains, two strains

281 from canary (PA1-09-92 and PA295-93) clustered in Clade A, precisely in

282 subclade A1 (Fowlpox virus) and not in Clade B (Canarypox virus).

283 Moreover, strains from the same avian species can display great nucleic acid

284 divergence: APVs from grey partridge cluster in two different subclades

285 (A1 and A2) with mean distance percentage between these two strains of

286 8.3\%. As for the strains from song thrush (PA9554 and PA9678), both were

287 considered members of subclade B1 although the mean distance between

288 the two strains was $2.7 \%$, versus $0.7 \%$ as the mean distance within subclade

289 B1 members. Similarly, PA147-07 from hooded crow is placed in subclade

290 B1 with nucleic acid divergence of $3.4 \%$. These results further sustain what

291 is reported for some APV strains from sparrows, falcons and pigeons

292 (Lüschow et al., 2004; Jarmin et al., 2006) and confirms that sequences of

293 isolates taken from the same species can be found in different sub-clades or

294 even different clades. This supports the evolutionary taxonomy of the host

295 does not appear to have a major role in driving APV evolution as reported in

296 previous reports (Jarmin et al., 2006). Alternatively, it is not possible to

297 exclude P4b gene is inappropriate for a correct evaluation of evolutionary

298 taxonomy. The possible consequences of the ancient and empirical use of

299 APV strains of different origin (chicken and pigeon) for immunization of

300 other avian species should also be considered. In this context, another report

301 (Adam et al., 2005) described identical P4b sequences in six different

302 genera of free-ranging birds in Virginia (USA). Our results cannot sustain

303 such finding as all the obtained P4b sequences display a certain degree of

304 nucleic acid divergence. It should be considered the fifteen clinical isolates 
305 of this study come all from Northern Italy, but they were collected in a very

306 long time span and in different periods. Nonetheless, the ability of APV

307 specific strains to naturally infect multiple avian species requires further

308 investigations.

309 Amplification of the gene fpv140 was carried out as it was proposed as a

310 diagnostic marker to easily distinguish between Clade A and Clade B

311 (Jarmin et al., 2006). Unexpectedly, only 7 out of 17 strains gave positive

312 results (Figure 3) including the two vaccine strains. It was well known this

313 marker fails with Clade C (Psittacinepox virus) and subclade A3, but none

314 of the seventeen strains cluster in those clade and subclade. Consequently,

315 the lack of amplification we observed for most strains reduces the

316 applicability of fpv140 as a diagnostic marker. As for the seven samples

317 with positive results for fpv140 gene, it is noteworthy that strain PA295-93

318 from canary belongs to Clade A (Figure 2) but yielded a 2400-bp product.

319 (Figure 3). This contrasts with previous findings by Jarmin et al. (2006).

320 Although these findings should be confirmed by detailed investigations on

321 larger APV collections, they suggest it is necessary to re-evaluate the role of

322 gene fpv140 as a target for easy distinction between APV clades.

323 Nevertheless, fpv140 gene can still be considered as a potential useful

324 addition to gene P4b in molecular biological characterization of APVs as

325 reported by Jarmin et al. (2006) and Rampin et al. (2007), though there is 326 still a need for other genome markers. 


\section{CONCLUSION}

330 The virological and molecular biological characterization of the strains

331 included in this study further detail the wide host range of these viruses.

332 These analyses of scarcely or previously uncharacterised APV strains

333 allowed the submission to GeneBank of new sequences of P4b gene now

334 available for further epidemiological investigations. The unexpected

335 limitations to the use of fpv140 gene for molecular biological

336 characterization of APVs underline the importance to undertake similar

337 studies on wider genomic regions aimed at identifying new pan-genus

338 markers, such as the P4b locus, that would permit more insight into this

339 large viral group.

\section{Acknowledgements}

342 This study was supported by funds from Università Statale di Milano (PUR

343 2008). We thank Dr Paul Boettcher for linguistic revision.

\section{REFERENCES}

346 Bolte, A.L., Meurer, J. \& Kaleta, E.F., 1999. Avian host spectrum of avipoxviruses. Avian Pathol. 28, 415-432.

348 Gubser, C., Hué, S., Kellam, P., Smith, G.L., 2004. Poxvirus genomes: a phylogenetic analysis. J. Gen. Virol. 85, 105-17. reaction for the diagnosis of fowl poxvirus infection. J. Virol.

353 Jarmin, S., Manvell, R., Gough, R.E., Laidlaw, S.M., Skinner, M.A., 2006.

354 Avipoxvirus phylogenetics: identification of a PCR length 355 polymorphism that discriminates between the two major clades. J. $356 \quad$ Gen. Virol. 87, 2191-2201. 
Kim, T.J., Schnitzlein, W.M., McAloose, D., Pessier, A.P. \& Tripathy, D.N., 2003. Characterization of an avianpox virus isolated from an Andean condor (Vultur gryphus). Vet. Microbiol. 96, 237-246.

Krone, O., Essbauer, S., Wibbelt, G., Isa, G., Rudolph, M., Gough, R.E., 2004. Avipoxvirus infection in peregrine falcons (Falco peregrinus) from a reintroduction programme in Germany. Vet. Rec. 154, 110113.

Kumar, S., Tamura, K., Jakobsen, I.B., Nei, M., 2001. MEGA2: molecular evolutionary genetics analysis software. Bioinformatics. 17, 1244-5.

Lüschow, D., Hoffmann, T., Hafez, H.M., 2004. Differentiation of avian poxvirus strains on the basis of nucleotide sequences of $4 \mathrm{~b}$ gene fragment. Avian Dis. 48, 453-62.

Rampin, T., Pisoni, G., Manarolla, G., Gallazzi, D., Sironi, G., 2007. Epornitic of avian pox in common buzzards (Buteo buteo): virus isolation and molecular biological characterization. Avian Pathol. $36,161-5$.

Rinaldi, A., Mahnel, H., Nardelli, L., Mandelli, G.C., Cervio, G., Valeri, A., 1972. Charakterisierung eines Wachtelpockenvirus. Zentralbl. Veterinarmed. B. 19, 199-212.

Thompson, J.D., Higgins, D.G., Gibson, T.J., 1994. CLUSTAL W: improving the sensitivity of progressive multiple sequence alignment through sequence weighting, position-specific gap penalties and weight matrix choice. Nucleic Acids Res. 22, 4673-80.

Tripathy, D.N., Reed, W.M., 1998. Pox. In: Swayne, D.E., Glisson, J.R., Jackwood, M.W., Pearson, J.E., Reed W.M (Eds.), Isolation and Identification of Avian Pathogens, 4th edn., New Bolton Center, PA: American Association of Avian Pathologists, pp. 137-140.

Tripathy, D.N., Schnitzlein, W.M., Morris, P.J., Janssen, D.L., Zuba, J.K., Massey, G., Atkinson, C.T., 2000. Characterization of poxviruses from forest birds in Hawaii. J. Wildl. Dis., 36, 225-230.

Tripathy, D.N., and Reed W.M., 2003. Pox. In: Saif, Y.M., Barnes, H.J., Fadly, A.M., Glisson, J.R., McDougald, L.R. and Swayne, D.E. (Eds.), Diseases of Poultry (cd version). 11th edn, Iowa State Press , Ames, pp. 253-269. 
391 Tulman, E.R., Afonso, C.L., Lu, Z., Zsak, L., Kutish, G. F. \& Rock, D.L., 392 2004. The genome of canarypox virus. J. Virol. 78, 353-366.

393 Weli, S.C., Traavik, T., Tryland, M., Coucheron, D.H., Nilssen, O., 2004. 394 Analysis and comparison of the $4 \mathrm{~b}$ core protein gene of 395 avipoxviruses from wild birds: evidence for interspecies spatial 396 phylogenetic variation. Arch Virol. 149, 2035-46.

397

398 
Figure captions

400

401 Figure 1. PCR amplification of the P4b gene from the the APV isolates of this study. Lane M, DNA size marker (100-bp DNA ladder); CTRL-, negative reagent control. See Table 1 for virus abbreviation.

404

405 Figure 2. Phylogenetic tree of nucleotide sequences of the $4 \mathrm{~b}$ core protein 406 gene of APV isolated in this study (marked with asterisk *), reference APV sequences and the MOCV orthologue sequence, rooted on MOCV. The tree was obtained by the neighbour-joining method calculated with the Jukes and Cantor model. Bootstrap testing of phylogeny was performed with 1000 replications and values equal to or greater than 70 are indicated on the branches (as a percentage). The length of each bar indicates the amount of evolution along the horizontal branches as measured by substitution per site. APV Clades A to C and subclades are labelled. Reference

417 Figure 3. PCR amplification of the fpv140 gene from the the APV isolates of this study. Lane M, DNA size marker (1000-bp DNA ladder); CTRL-, negative reagent control. See Table 1 for virus abbreviation. 
Table 1 - Details of APVs used in this study

\begin{tabular}{|c|c|c|c|c|c|}
\hline Code & Avian species of origin & Nature & Date & Origin & $\begin{array}{l}\text { Accession } \\
\text { numbers }\end{array}$ \\
\hline FWPVD & Chicken (Gallus gallus) & Commercial vaccine & -- & Europe & *AM050380 \\
\hline $\begin{array}{c}\text { Diftosec CT (Merial) } \\
\text { CNPVV } \\
\text { Duphar-Fort Dodge }\end{array}$ & Canary (Serinus canarius) & Commercial vaccine & - & Europe & -- \\
\hline QP-241 $\S$ & $\begin{array}{c}\text { Japanese quail (Coturnix } \\
\text { japonica) }\end{array}$ & Clinical isolate & 1963 & Northern Italy & GQ180200 \\
\hline PA4078 & Grey Partridge (Perdix perdix) & Clinical isolate & $12-1978$ & Northern Italy & GQ180201 \\
\hline PA7746 & Canary (Serinus canarius) & Clinical isolate & $12 / 1985$ & Northern Italy & GQ180203 \\
\hline PA1-09-92 & Canary (Serinus canarius & Clinical isolate & 09/1992 & Northern Italy & GQ221269 \\
\hline PA7761 & Grey Partridge (Perdix perdix) & Clinical isolate & 09-1986 & Northern Italy & GQ180204 \\
\hline PA9554 & Song Thrush (Turdus philomelos) & Clinical isolate & $10-1991$ & Northern Italy & GQ180205 \\
\hline PA9678 & Song Thrush (Turdus philomelos) & Clinical isolate & 02-1992 & Northern Italy & GQ180206 \\
\hline PA9922 & Pheasant (Phasianus colchicus) & Clinical isolate & $12-1992$ & Northern Italy & GQ180207 \\
\hline PA295-93 & Canary (Serinus canarius) & Clinical isolate & 1993 & Northern Italy & GQ180208 \\
\hline PA303-94 & Pigeon (Columba livia) & Clinical isolate & 09-1994 & Northern Italy & GQ180209 \\
\hline PA153-05 & Common Buzzard (Buteo buteo) & Clinical isolate & 09-2005 & Northern Italy & **EF016108 \\
\hline PA262-06 & Gyrfalcon (Hierofalco rusticolus) & Clinical isolate & $11-2006$ & Northern Italy & GQ180210 \\
\hline PA147-07 & Hooded crow (Corvus corone) & Clinical isolate & $06-2007$ & Northern Italy & GQ180211 \\
\hline PA213-07 & Turkey (Meleagris gallopavo) & Clinical isolate & $10-2007$ & Northern Italy & GQ180212 \\
\hline PA248-07 & Dunnock (Prunella modularis) & Clinical isolate & $10-2007$ & Northern Italy & GQ180213 \\
\hline
\end{tabular}

Legend: -- not available; $§$ Rinaldi et al., 1972; *Jarmin et al, 2006; **Rampin et al., 2007 
Table 2 - Details of poxvirus sequences obtained from GenBank.

\begin{tabular}{|c|c|c|c|}
\hline Virus name & Abbreviation & Host & GenBank Accesion no \\
\hline Turkeypox 2/11/66 & TKPV66 & Turkey & AM050387 \\
\hline Turkeypox 10/12/98 & TKPV98 & Turkey & AM050388 \\
\hline Turkeypox GB 134/01 & TKPV134/01 & Turkey & AY530304 \\
\hline Sparrowpox 9037 31/5/66 & SRPV9037 & Sparrow & AM050389 \\
\hline Sparrowpox $903731 / 5 / 66 / 23$ & SRPV23 & Sparrow & AM050390 \\
\hline Starlingpox /27 & SLPV & Starling & AM050391 \\
\hline Houbarapox 1252/98/42 & HOPV1252 & Houbara bustard & AM050381 \\
\hline Macawpox 1305/86 & MCPV & Macaw & AM050382 \\
\hline Parrotpox 364/89 & PRPV & Parrot & AM050383 \\
\hline Falconpox 1381/96 & FLPV1381 & Falcon & AM050376 \\
\hline Albatrosspox 353/87 & ABPV & Black-browed albatross & AM050392 \\
\hline Agapornis APIII & AGPV & Agapornis & AY530311 \\
\hline Canarypox ATCC VR-111 & CNPVATCC VR-111 & Canary & AY318871 \\
\hline Canarypox GB 724/01-22 & CNPV72401 & Canary & AY530309 \\
\hline Canarypox 1445/97/33 & CNPV1445 & Canary & AM050375 \\
\hline Duphar; Fort Dodge & CNPVV & Canary & AM050384 \\
\hline Fowlpox FPV-VR250 & FWPVVR250 & Chicken & AY453172 \\
\hline Fowlpox HP-B & FWPVHPB & Chicken & AY530302 \\
\hline Fowlpox HP1-444 (FP9) & FWPVFP9 & Chicken & AJ581527 \\
\hline Fowlpox Mild (Websters; Fort Dodge) & FWPVM & Chicken & AM050378 \\
\hline Fowlpox Nobilis Variole W (Intervet) & FWPVN & Chicken & AM050379 \\
\hline Fowlpox Diftosec CT (Merial) & FWPVD & Chicken & AM050380 \\
\hline Fowlpox 174/4/04 & FWPV174 & Chicken & AM050377 \\
\hline Falconpox GB362-02 & FLPV36202 & Falcon & AY530306 \\
\hline Great titpox GTPV-256 & GTPV-256 & Great tit & AY453175 \\
\hline Great titpox GTPV-A310 & GTPVA310 & Great tit & AY453173 \\
\hline Great titpox-A311 & GTPVA311 & Great tit & AY453174 \\
\hline Ostrichpox GB 724/01-20 & OSPV & Ostrich & AY530305 \\
\hline Pigeonpox Peekham 19/11/75 & PGPVP & Pigeon & AM050385 \\
\hline Pigeonpox 950 24/3/77 & PGPV950 & Pigeon & AM050386 \\
\hline Pigeonpox B7 & PGPVB7 & Pigeon & AY453177 \\
\hline Pigeonpox TP-2 & PGPVTP2 & Pigeon & AY530303 \\
\hline Sparrowpox DD1258 & SRPVDD1258 & Sparrow & AY530307 \\
\hline Sparrowpox GB 320/02 & SRPV32002 & Sparrow & AY530308 \\
\hline Sparrowpox GB 182/98 & SCPV18298 & Stone curlew & AY530310 \\
\hline
\end{tabular}


Quailpox

Mourning dove WCV33-03

Red-Tailed Hawk WCV1419-03
Quail

DQ873809

WCV33-03

Mourning dove

DQ131892

WCV1419-03

Red-Tailed Hawk

DQ131901 
Table 3 - Results of APV isolation in commercial and SPF embryonated eggs of the clinical isolates used in this study: gross and microscopic findings on CAMs.

\begin{tabular}{|c|c|c|c|}
\hline \multirow{2}{*}{ APV clinical isolate } & \multicolumn{2}{|c|}{ Gross lesions on CAMs } & \multirow{2}{*}{$\begin{array}{c}\text { Microscopic lesions on } \\
\text { CAMs }\end{array}$} \\
\hline & pocks & thickening & \\
\hline QP-241 & + & mild/moderate & $\mathbf{P}$ \\
\hline PA4078 & - & moderate & $\mathbf{P}$ \\
\hline PA7746 & - & moderate & $\mathbf{P}$ \\
\hline PA1-09-92 & - & $\mathrm{mild} /$ moderate & $\mathbf{P}$ \\
\hline PA7761 & - & moderate & $\mathbf{P}$ \\
\hline PA9554 & +++ & severe & $\mathbf{P}$ \\
\hline PA9678 & +++ & severe & $\mathbf{P}$ \\
\hline PA9922 & - & & $\mathbf{P}$ \\
\hline PA295-93 & ++ & mild/moderate & $\mathbf{P}$ \\
\hline PA303-94 & - & not observed & $\mathbf{P}$ \\
\hline PA153-05 & + & mild & $\mathbf{P}$ \\
\hline PA262-06 & & severe & $\mathbf{P}$ \\
\hline PA147-07 & - & $\mathrm{mild} /$ moderate & $\mathbf{P}$ \\
\hline PA213-07 & ++ & moderate/severe & $\mathbf{P}$ \\
\hline PA248-07 & - & $\operatorname{mild} /$ moderate & $\mathbf{P}$ \\
\hline
\end{tabular}

Legend: +++: > 5 pocks; ++: 3-5 pocks; +: 1-2 pocks; P: present 


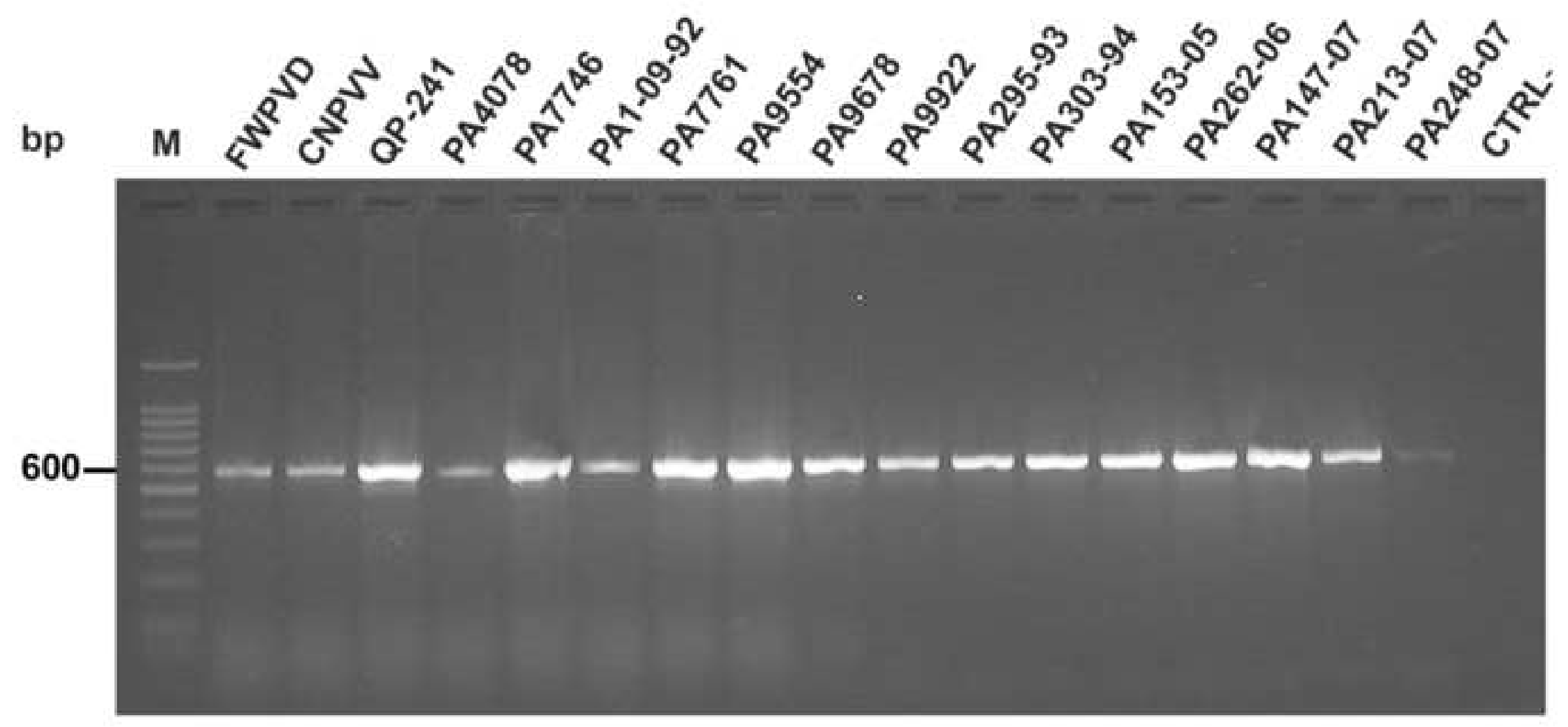




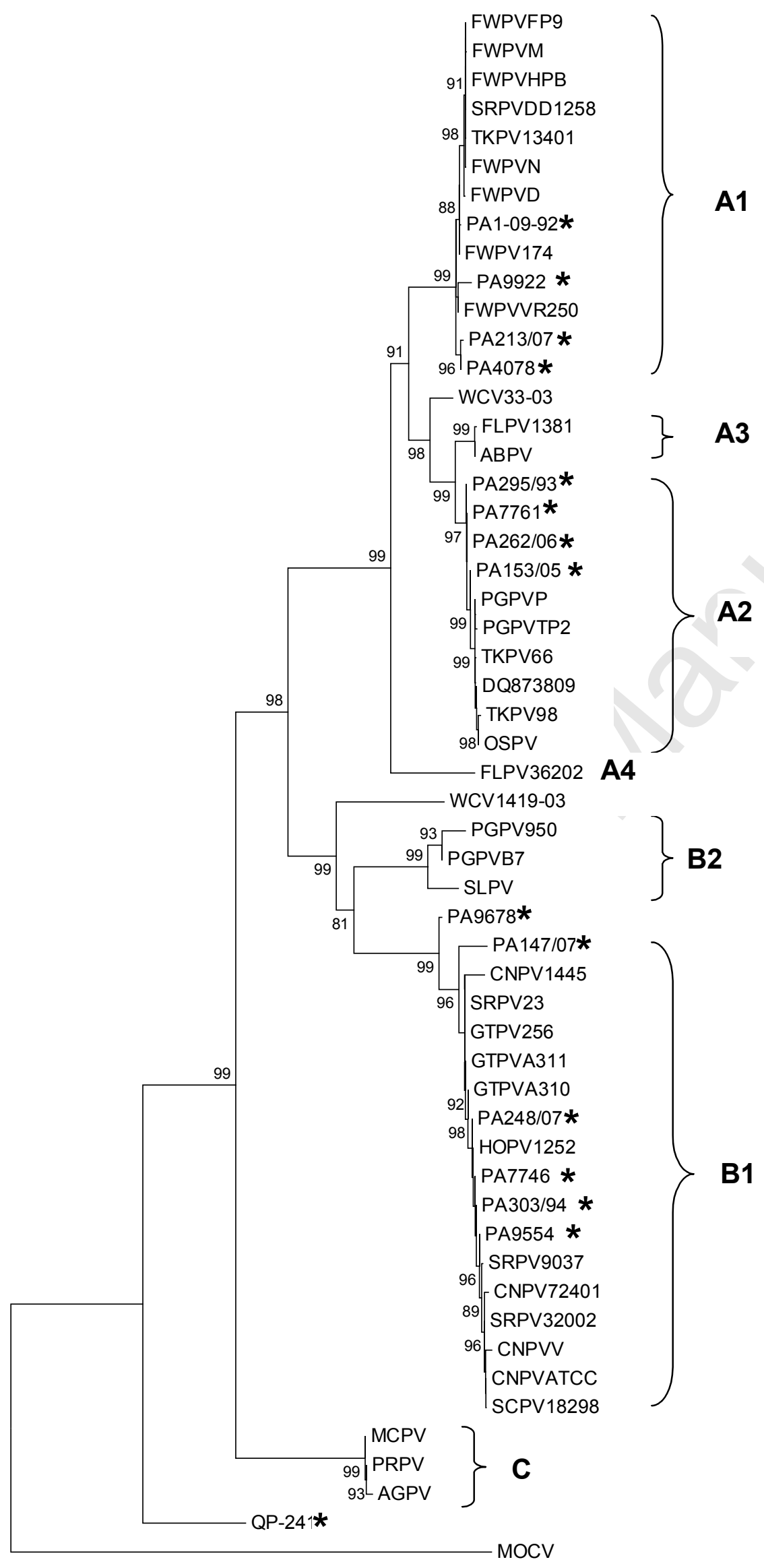

0.1 


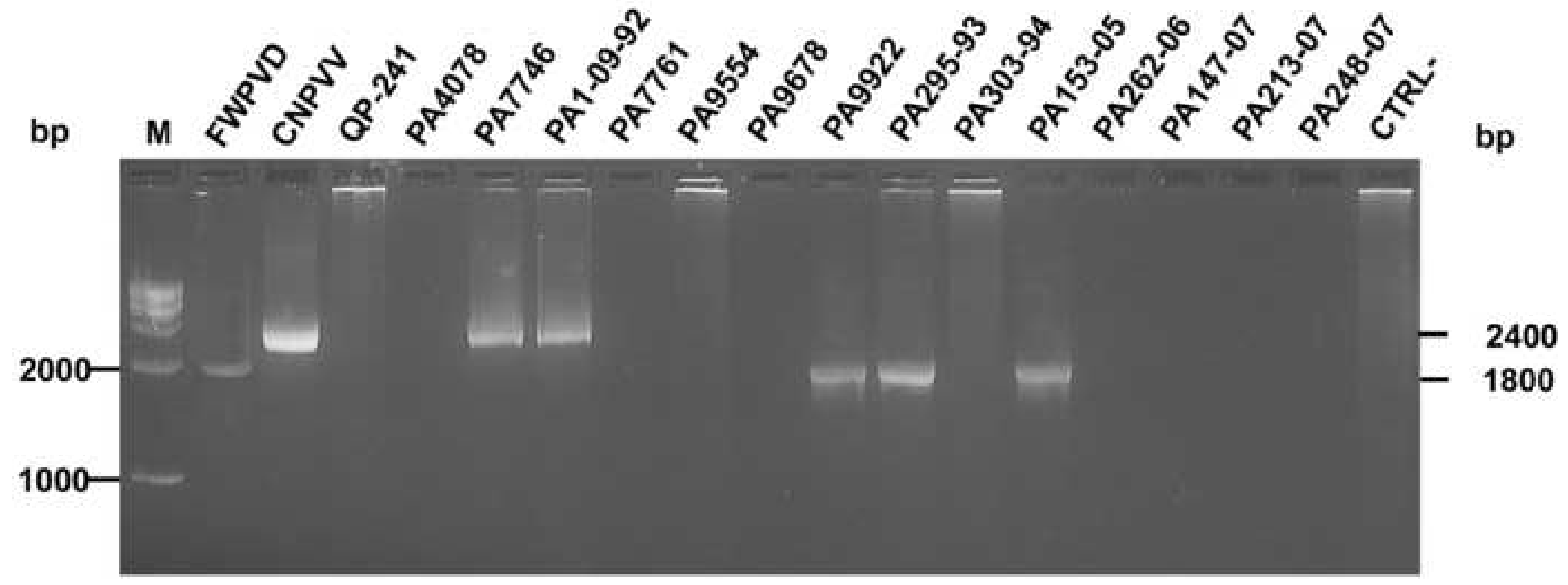

